\title{
ORGANIZATIONAL COMPETENCES FOR THE ROMANIAN TOURISTIC FIRM AND WAYS TO CONCEIVE THEM
}

\author{
Lecturer PhD Student Mălina Cordoş, “1 Decembrie 1918” University of Alba Iulia, e-mail: \\ malinacordos@yahoo.com
}

\begin{abstract}
Between the vocation and the competence of an organization there is a complex and a subtle relation. If the vocation it means searching and finding the need or the need type that will be covered, the competence means to know, to want and to be capable to deliver the services that can produce the user satisfaction in efficiency conditions for the firm.
\end{abstract}

Keywords: competences, vocation, capability, knowledge

JEL Codes: D21, D83, L21

The implication of the vocation presumes not only the presence but the use of the organizational learning too. A traveling firm which is identifying to be an unsatisfied need the assurance of some complementary services for a trip (baby-sitter, toilet services and watching the pets etc.) doesn't mean that it automatic disposes of the knowledge potential and of the abilities potential that will allow to make a good cover of the respective needs. On the other hand, in practice we can see frequent the situation in which the firm disposes of some competences that are acquired through the organizational learning but which are not corresponding with the vocation but which are corresponding only to the products making, to the services, to the standards works that assure the survival of the respective firm.

The organizational competence term is relegating to the knowledge potential and to the action potential in report with the established targets, in a given medium, as a result of the capitalization of the individual knowledge and abilities and that belongs to that organization.

Starting from the information, knowledge and creativity importance in a society that is underlining to be a informational society (the main object of the multiples studies from the last years, people saying of a revolution to the society, respective of an economy that is based on knowledge ${ }^{1}$, of an firm based on knowledge ${ }^{2}$, and associate to these, of an management based on knowledge ${ }^{3}$ ), many specialists say that the organization identity is given especially by the action that is displayed by the respective organization in a certain moment and by it's competences, the things that it can do in conditions of efficiency and of effectiveness.

It is obvious to anybody that is working in a firm or is leading a department that the products, the services, the information delivered at a certain moment do not produce a complete capitalization of the intellectual, professional and emotive potential of the personal and, also, do not produce a complete capitalization of the organizational potential of the firm, as an ensemble.

\footnotetext{
${ }^{1}$ The economy based on knowledge ${ }^{1}$ - a new economy characterized by: the primary knowledge in all the spheres of the economic activities, the intellectual property detain a noticeable percent in the national patrimony; the concentration of the economic activities, not on the good creation, but on the information treatment, on the good accumulation and the production of the good-knowledge, the knowledge capital; the main content of the intellectual content is a special capital, intangible, fluid, of which the exclusive possession is difficult to be assured; proliferation of the equipments and of the symbolic products, concomitant with the relative diminution of the physical products, etc. (O.N. page49)

${ }^{2}$ The firm based on knowledge ${ }^{2}$, defined to be that enterprise which, on the base of an balanced approach from the economic, ecologic and social points of view capitalize at a superior level the knowledge and other resources which belong to a firm and who attract them generating for long periods, multidimensional efficiency and performances which are validated on the market and approved by the society (ON,106)

${ }^{3}$ as sciences, the management based on knowledge, consist in studying the processes and the managerial relations based on knowledge, in discovering the legitimate actions managed by these and in conceiving the new systems, methods, technical, etc., to prospect the increase of the organizations functionality and performances, capitalizing the big valences of the knowledge.
} 
Important reserves of creativity and/or efficacy remain unused because of some obstacles that are created by the managers, employees, clients, providers, etc. The organizational competences are based on the individual knowledge, abilities, aptitudes, but there are not reducing to their sample total.

The correct management of the components that are available to employees and their transformation in real organizational competences is relegating to ability, to the management art, to a certain type of interest for success, performance, and competition.

Beyond the fact that the competences management created, for more than a decade, multiple attitudes and theoretical opinions, in practice the competences management was implicit manifested with the appearance of the organizations. Intuitive, some organizations known how to decode what today are called a paradox of the modern firms: organizations that dispose of a personal with a higher qualification and who make the proof of a modest performances.

A succinct characterization of the organizational competences notices the fact that they are:

- acknowledge capacities of an employee or of a group to obtain useful results and performances that are expected to be obtained as a result of the development of some activities

- result of a certain process of organizational learning

-specialized, belonging to a certain domain and oriented to a certain purpose

- perfect through the application

- obtained by grouping the competences detained by the employees of the organization

The volume, the structure and the quality of the organizational competences give the strategic capability of a firm. In the measure in which the firm dispose of rare competences, that are difficult to reproduce, that bring prestige for the respective organization and, implicit, that bring profit for the organization, the firm is assuring a privileged place in it's competitive medium. This presumes that the firm has key competences C.H.Prahalad, G.Hamel (The core competence of the organization, Harvard Business Review, May/June, 1990), unique characteristics that allow to the holder enterprise to realize new products and to extend its competitive capacity in a rapid rhythm.

Characterizing the key competences it can be noticed that these:

-assure the enterprise identity that shows what it can do best

- create or contribute in a decisive manner to the obtaining of a long term competitive advantage

- are impossible or very difficult to be imitated by the competitors

- offer some advantages to the clients as a result of the quality, of the price, of the distribution manner, etc.

- prove elasticity and they can be applied to other products then the products that were used in the first place.

Appealing some different kinds of classifications that we can find in the specialized literature, the competences types that can be found in a tourism firm can be presented as it follows:

\section{The inclusion sphere}

\section{Type 1: Individuals}

Contain: Knowledge, abilities, the behavior of the people that are hired that allow them to realize the tasks at the level of the standards

Expression mode: The communication capacity, the empathy capacity, the promptitude and the fairness of the services

\section{Type 2: Organizational}

Contain: The capacity of the organization to initiate, to display and to develop certain activities at a level of performance that is similar or superior with the level of the rivals 
Expression mode: The elaboration and the implementation of some strategies that will allow the forming of a favorable and solid image, the attraction and the fidelity of the clients

\section{The differentiation capacity of the firm}

\section{Type 1: Generics}

Contain: The minimum competences set that allow the running of an organization in a competitive medium

Expression mode: The capacity of organizing and coordinating the typical activities of the tourism firm ensemble, the decisional capacity to suit to the environment

\section{Type 2: Specifics}

Contain: The set of the competences that are detained by some organizations, which are generated by the particularities of the activity and by the firm individuality

Expression mode: for the tourism agency: mobility and flexibility in proportion with the seasons, the request changes; for the hotel: hospitality, comfort, safety; for the restoration: the food preparation and serving

\section{The contribution to the obtaining of a competitive advantage}

\section{Type 1: Hackneyed}

Contain: Competences set with a common character detained by any firm from a branch which will allow to exist in normal conditions of working

Expression mode:Reception, accommodation, transport, public alimentation, amusement

\section{Type 2: Distinctive}

Contain: Competences detained only by certain firms which allow them differentiation from other firm very similar as type with them

Expression mode: Unique food proposals; programs packages that are special conceived for certain tourists categories; supplementary services comparative with the rivals

\section{Type 3: Emergent}

Contain: Competences that are just licking into a shape and which assure to their holders a certain development potential, in perspective

Expression mode: The tourism agency: educative, scientific, religious tourism; hotel: banking, amusement; public alimentation: vegetarian diets

By the size and by the complexity of the displayed activities the organisations can have one or more vocations, being that what many people are calling the "firm competences base". An analysis model of the firm vocation can be like the following one:

The analysis of the vocation of the tourism firm

\begin{tabular}{|l|l|l|l|l|}
\hline Nr. & Vocation & The identified need & $\begin{array}{l}\text { Products/services } \\
\text { that are offered }\end{array}$ & $\begin{array}{l}\text { Distinctive } \\
\text { competences }\end{array}$ \\
\hline 1 & Hotel & Repose, comfort, safety & $\begin{array}{l}\text { Accommodation } \\
\text { Supplementary } \\
\text { services }\end{array}$ & $\begin{array}{l}\text { Specialized } \\
\text { services }\end{array}$ \\
\hline 2 & Public alimentation & Food, hygiene, comfort & $\begin{array}{l}\text { Various food and } \\
\text { drinks }\end{array}$ & $\begin{array}{l}\text { Unique recipes } \\
\text { in the country }\end{array}$ \\
\hline
\end{tabular}


The competences analysis also imposes other points of view, like "the V.R.I.O. analysis" according to which a competence is more important if it has good responses to the following requirements:

profit

V - Value, when the respective competence is capable to generate a supplementary

$\mathbf{R}$ - Rarity, if we can find it in the same shape and with the same intensity in a restricted number of organizations

I - Inimitable, if the possibility to reproduce it and imitate it by the new come on the specific market is reduce

O - Organization, if the organization disposes of the strategic capability to exploit it in an effective manner.

An analysis model of the functional competences of the tourism organization and of its influences on the market situation of the firm is represented in the following mode:

Table no. 2

The VRIO analysis of the functional competences of the firm

\begin{tabular}{|c|c|c|c|c|c|c|c|c|c|}
\hline $\begin{array}{l}\text { Domain/ } \\
\text { competence }\end{array}$ & $\begin{array}{c}\text { The } \\
\text { inclusio } \\
\text { n sphere }\end{array}$ & $\begin{array}{c}\text { Different } \\
\text { iation }\end{array}$ & $\begin{array}{c}\text { The } \\
\text { contributi } \\
\text { on to the } \\
\text { competitiv } \\
\text { e } \\
\text { advantage }\end{array}$ & Dispersal & $\mathbf{V}$ & $\mathbf{R}$ & I & $\mathbf{O}$ & $\begin{array}{l}\text { The } \\
\text { enterprise } \\
\text { situation }\end{array}$ \\
\hline $\begin{array}{l}\text { I. Searching- } \\
\text { development: } \\
\text { 1.1. The } \\
\text { capacity to } \\
\text { renew the } \\
\text { tourism } \\
\text { services }\end{array}$ & $\begin{array}{l}\text { Organiza } \\
\text { tional }\end{array}$ & Specifics & Distinctive & $\begin{array}{l}\text { Transvers } \\
\text { e, } \\
\text { inter- } \\
\text { organizati } \\
\text { on }\end{array}$ & $X$ & $X$ & - & $X$ & Excellency \\
\hline $\begin{array}{l}\text { 1.2. The } \\
\text { elaboration of } \\
\text { some market } \\
\text { strategies with an } \\
\text { accent on the } \\
\text { partner image }\end{array}$ & $\begin{array}{l}\text { Individu } \\
\text { als }\end{array}$ & Specifics & Emergency & Located & $X$ & $X$ & $X$ & - & Tapping \\
\hline $\begin{array}{l}\text { II. Public } \\
\text { alimentation } \\
\text { 2.1. Alimentation } \\
\text { technologies }\end{array}$ & $\begin{array}{l}\text { Organiza } \\
\text { tional }\end{array}$ & Generic & Hackneyed & Located & $X$ & - & - & - & Survival \\
\hline $\begin{array}{l}\text { 2.2. Prescription } \\
\text { for products - } \\
\text { warm and cold } \\
\text { kitchen } \\
\end{array}$ & $\begin{array}{l}\text { Organiza } \\
\text { tional }\end{array}$ & Generic & Hackneyed & Located & $X$ & - & - & - & Survival \\
\hline
\end{tabular}

The importance of the identification of the key competences assure the firm vocation and so assure to that firm a sure and a durable advantage in the competition with the similar firms. 


\section{References}

1. Căprărescu, G. - Managementul strategic al firmei de comerț şi turism, Editura Rosetti, Bucureşti, 2005

2. Nicolescu, Ov., Nicolescu, L.- Economia, firma şi managementul bazat pe cunoştințe, Editura Economică, Bucureşti, 2005.

3. Neagu, V. - Managementul turistic şi al serviciilor turistice, Editura Sylvi, Bucureşti, 2002

4. Stremțan F., Ispas I., Moisă C. - Marketing turistic, Editura Didactică a Universității “1 Decembrie 1918", Alba Iulia, 2005.

5. Hinescu, A., Cordos, M., Moisă, C. - Managementul general al intreprinderii. Teste. Probleme. Sudii de caz Seria Didactica, Universitatea „1 Decembrie 1918” Alba Iulia, 2005

6. Phd. Hinescu, A., Cordoş, M. - Distribuția şi promovarea produsului turistic, Revista de comert, nr.4, aprilie 2004

7. Hinescu, A., Cordoş, M. - Aspecte privind analiza mediului de marketing şi tendințele acestuia, Revista de comert, nr.5, mai 2005

8. Phd. Hinescu, A., Cordoş, M. - Specificul şi interacțiunea distribuției şi promovării în turism, Sesiunea ştiințifică „Repere ale dezvoltării la început de mileniu” ,Universitatea „Dimitrie Cantemir”, Târgu Mureş, 2003

9. Cordoş, M. - Factorii psihologici determinanți ai comportamentului consumatorului de servicii turistice şi tipuri de consumatori, Analele Universității din Oradea, 2003

10. Phd. Hinescu, A., Cordoş M., - Alternative strategice manageriale în distribuția şi promovarea produsului turistic, Sesiunea ştiințifică internațională ,Economia românească prezent şi perspective", Suceava, 27-28 iunie 2003

11. Cordoş, M. - Unele considerații privind noile tendințe în turismul românesc Simpozionul Internaţional „UNIVERSITARIA ROPET 2003”, 16-18 octombrie 2003, Editura Universitas, Petroşani

12. Cordoş, M. - Tradition and Modernism in Romanian Industry of Hospitality The 17th Biennal International Congress TOURISM AND HOSPITALITY INDUSTRY, "New Trends in Tourism and Hospitality Management", Faculty of Tourism and Management, Opatija, Croația, 14-16 aprilie 2004

13. Cocoi, L. - The process of taking decisions in the management activity, Simpozionul International „Le Management de la Transition” 4-5 nov. 2004, Târgovişte, Editura Economică, 2004

14. Lazăr, I., Dragolea, L. - The quality of services- a premise of the rural tourism development in Romania, International Conference "Sustainable development in the balkan area: vision and reality", Alba Iulia, Romania, 18-20 July 2007 